\title{
PEMBERDAYAAN USAHA MIKRO TAPE MENUJU DIGITALISASI
}

\author{
Nungky Viana Feranita \\ Progam Studi Ilmu Administrasi Niaga \\ Sekolah Tinggi Ilmu Administasi Pembangunan Jember \\ *Email: nungky_viana@stiapembangunanjember.ac.id
}

\begin{abstract}
ABSTRAK
Sebagian besar UMKM yang ada di Desa Jatisari adalah produksi tape. Pelaksanaan pemberdayaan ini ditujukan kepada usaha mikro tape milik Ibu Masfufah. Pandemi Covid-19 ini memberikan dampak terhadap pendapatan, penjualan, dan jumlah karyawan Ibu Masfufah. Dampak dari peristiwa ekstrem pandemi Covid-19 dapat dikurangi dengan menggunakan digitalisasi. Untuk mempersiapkan digitalisasi, usaha mikro tape perlu melakukan perbaikan terhadap manajemen usaha dan pengemasan produknya. Pelaksanaan kegiatan dimulai tanggal 7 sampai dengan 13 Desember 2020 di usaha mikro tape milik Ibu Masfufah, Desa Jatisari, Kecamatan Jenggawah,

Kabupaten Jember. Kegiatan ini melibatkan 4 mahasiswa dari Program

Studi Ilmu Administrasi Negara dan Niaga. Metode kegiatan yang dilaksanakan yaitu pengurusan SKU dari Dinas Koperasi dan Usaha Mikro

Kabupaten Jember, pelatihan pencatatan keuangan secara terstruktur, pengemasan produk tape yang lebih menarik, dan pemasaran produk tape secara online. Tujuan kegiatan adalah meningkatkan pengetahuan, ketrampilan, dan pendapatan usaha mikro tape milik Ibu Masfufah melalui digitalisasi.

Hasil kegiatan ini adalah usaha mikro tape milik Ibu Masfufah telah memiliki SKU dari Dinas Koperasi dan Usaha Mikro Kabupaten Jember. Ibu Masfufah mampu melakukan pencatatan keuangan secara terstruktur dengan memisahkan keuangan pribadi dan usaha, serta mampu menggunakan model akuntansi sederhana. Produk tape dikemas dengan besek dan kardus serta diberi label sehingga terlihat lebih menarik. Pemasaran produk semakin luas dengan dilakukannya pemasaran secara online melalui Facebook dan Instagram. Kata Kunci: Pemberdayaan, Usaha Mikro, Digitalisasi.
\end{abstract}




\section{Analisis Situasi}

Kebijakan social/physical distancing yang telah diterapkan oleh World Health Organization (WHO) pada masa pandemi Covid-19 berpengaruh signifikan terhadap pelaku usaha. Pembatasan tersebut memiliki dampak yang lebih parah terhadap UMKM dibandingkan dengan usaha besar. Faktanya, UMKM adalah yang paling rentan karena mereka cenderung memiliki cadangan modal yang lebih rendah, aset yang lebih sedikit, dan tingkat produktivitas yang lebih rendah daripada usaha yang lebih besar (OECD, 2020). Kegiatan UMKM di Indonesia juga terganggu karena tidak dapat beroperasi seperti biasanya sehingga permintaan dan pendapatan menurun (Lutfi et al., 2020). Covid-19 menimbulkan kecemasan bagi UMKM untuk tetap bertahan sehingga pelaku usaha mengubah model bisnisnya dengan memanfaatkan inovasi teknologi.

Untuk menghadapi dampak dari peristiwa ekstrem pandemi Covid-19, UMKM menggunakan digitalisasi (Papadopoulos et al., 2020). Digitalisasi telah mengubah cara bisnis dijalankan sehingga dapat menjadi sumber keunggulan kompetitif baru bagi perusahaan (Guo et al., 2020). UMKM dapat memperoleh keunggulan kompetitif yang berkelanjutan melalui digitalisasi apabila mereka memiliki jenis sumber daya ini. Oleh karena itu, UMKM perlu melakukan perubahan model bisnis dari yang semula bersifat konvensional menjadi model bisnis yang digerakkan oleh digitalisasi (Witschel et al., 2019). Namun, sangat sulit bagi UMKM untuk membangun model bisnis digital terutama dalam masa pandemi Covid-19.

Dalam konteks digitalisasi, sejumlah besar peluang bisnis baru muncul dan sekaligus menciptakan berbagai tantangan sehingga mengancam model bisnis yang sudah mapan. Digitalisasi berpotensi membantu UMKM merespons krisis yang disebabkan oleh Covid-19 secara efektif dengan mengaktifkan kapabilitas dinamis mereka (Vial, 2019). Digitalisasi mengacu pada penggunaan teknologi digital seperti teknologi informasi, komputasi, 
komunikasi, dan koneksi untuk mendorong perubahan organisasi (Vial, 2019; Bharadwaj et al., 2013; Sebastian et al., 2017).

Desa Jatisari, Kecamatan Jenggawah, Kabupaten Jember merupakan salah satu desa binaan Sekolah Tinggi Ilmu Administrasi (STIA) Pembangunan Jember selain Desa Sruni dan Desa Jatimulyo. Sejak tahun 2015, kegiatan pengabdian kepada masyarakat bagi dosen dan mahasiswa dilakukan di desa tersebut. Kegiatan pengabdian kepada masyarakat ini difokuskan pada usaha mikro tape milik Ibu Masfufah di Desa Jatisari. Berdasarkan hasil observasi yang dilakukan pada tanggal 3 November 2020 ditemukan fakta bahwa sebagian besar UMKM yang ada di Desa Jatisari adalah produksi tape.

Usaha mikro tape milik Ibu Masfufah didirikan sejak tahun 2004 dan bersifat usaha keluarga. Usaha tersebut didirikan dengan modal awal sebesar Rp1.500.000. Pandemi Covid-19 ini memberikan dampak terhadap pendapatan, penjualan, dan jumlah karyawannya (lihat Tabel 1).

Tabel 1. Perbedaan Sebelum dan Selama Covid-19

\begin{tabular}{|l|l|l|}
\hline & \multicolumn{1}{|c|}{ Sebelum Covid-19 } & \multicolumn{1}{c|}{ Selama Covid-19 } \\
\hline Pendapatan & $\mathrm{Rp} 7.000$ (harga/kg) $\times 250$ & $\mathrm{Rp} 7.000$ (harga/kg) $\times 150$ \\
& $\mathrm{~kg}=\mathrm{Rp} 1.750 .000,-$ & $\mathrm{kg}=\mathrm{Rp} 1.050 .000,-$ \\
\hline Penjualan & Penjualan mencapai 2,5 & Penjualan mengalami \\
& kuintal/hari dan bahkan & penurunan 1 kuintal \\
& saat bulan Ramadhan & sehingga penjualan saat \\
& penjualan bisa mencapai & ini hanya mencapai 1,5 \\
& 6 kuintal/hari & kuintal/hari \\
\hline Jumlah Karyawan & $2-3$ orang & 1 orang \\
\hline
\end{tabular}

Sumber: hasil wawancara dengan Ibu Masfufah

Selama proses produksi tape, Ibu Masfufah memperoleh pasokan bahan baku singkong dari daerah sekitar Kecamatan Mumbulsari dan Desa Seputih, Kecamatan Mayang karena di daerah tersebut harga singkong lebih murah yaitu Rp1.700 per kg. Kualitas singkong juga lebih baik jika dibandingkan dengan daerah lainnya dimana singkong dari ubi kayu jenis yang kuning atau singkong mentega sehingga lebih empuk, lembut dan berair. 
Untuk wilayah pemasaran, selama ini Ibu Masfufah hanya memasarkan tapenya secara offline ke pasar Ambulu. Tape juga dipasarkan ke tempat produksi oleholeh di Desa Tanjungrejo, Kecamatan Wuluhan yang digunakan sebagai bahan baku produksi oleholeh makanan khas Jember seperti suwar suwir, prol tape dan lain-lain.

\section{Landasan Teori}

\section{a. Digitalisasi}

Digitalisasi mengacu pada proses transformasi organisasi melalui adopsi teknologi digital (Sebastian et al., 2017; Vial, 2019), terutama dimanifestasikan dalam organisasi sebagai artefak digital, platform digital, infrastruktur digital, serta model bisnis dan manajemen digital. Teknologi digital adalah campuran dari teknologi informasi dan komunikasi terkomputerisasi dan dapat diklasifikasikan menjadi tujuh jenis: sosial, seluler, data besar, komputasi awan, Internet of Things (IoT), pengembangan platform, dan teknologi terkait Artificial Intelligence (AI).

Teknologi digital dapat diprogram, dapat dialamatkan, masuk akal, dapat dikomunikasikan, mudah diingat, dapat dilacak, dan dapat diasosiasikan. Dengan demikian, digitalisasi atau transformasi digital dapat membantu perusahaan mendapatkan dan mempertahankan keunggulan kompetitif dengan meningkatkan fleksibilitas dan ketahanan organisasi mereka dan dengan meningkatkan kapabilitas dinamis mereka.

Secara khusus, Guo et al.
(2020) mengusulkan bahwa
digitalisasi bermanfaat bagi
kemampuan dinamis perusahaan.
Pertama, digitalisasi membantu
perusahaan merasakan perubahan
lingkungan. Keuntungan besar dari
sumber daya digital dalam volume,
kecepatan, variasi, dan nilai
memungkinkan perusahaan untuk
mengumpulkan atau mengambil
kembali sumber daya informasi di
lingkungan eksternal dengan biaya
rendah. Selain itu, penerapan sistem
analisis data besar dan teknologi IoT
membantu perusahaan menyaring
informasi berharga melalui
komputasi berkecepatan tinggi


sehingga mereka dapat merasakan dan memprediksi perubahan lingkungan sampai batas tertentu.

Kedua, perusahaan dapat menangkap peluang dengan lebih baik dalam lingkungan krisis dengan bantuan teknologi digital. Dalam wabah Covid-19, digitalisasi telah menciptakan banyak peluang baru, dan bidang-bidang seperti pendidikan online, kerja online, dan pengiriman tanpa awak telah menunjukkan potensi besar. Lebih lanjut, sifat desentralisasi teknologi digital memecahkan hambatan dalam ruang dan waktu, dan mempromosikan interaksi antara perusahaan fokus dan rekan pencipta nilai mereka, sehingga meningkatkan peluang mereka dalam jaringan terbuka. Selain itu, teknologi big data volume tinggi dan teknologi analisis cloud berkecepatan tinggi telah meningkatkan akurasi analisis bisnis, membantu perusahaan mengidentifikasi peluang potensial di lingkungan yang kompleks. Selain itu, teknologi digital telah mengubah cara-cara di mana peluang baru dieksploitasi, dengan cara yang lebih baru daripada yang telah ditentukan sebelumnya.

Terakhir, digitalisasi memungkinkan perusahaan untuk mengkonfigurasi ulang sumber daya mereka untuk menanggapi krisis. Digitalisasi meningkatkan sumber daya perusahaan yang tersedia dalam cakupan, skala, dan fleksibilitas. Misalnya, teknologi informasi dan komunikasi mengurangi biaya kegiatan koordinasi dalam perusahaan dan mempromosikan alokasi sumber daya yang fleksibel. Selain itu, teknologi digital secara fundamental telah membentuk ulang proses bisnis, produk, dan layanan, serta hubungan antar-perusahaan, sehingga sangat mengurangi kesulitan dan biaya pemindahan sumber daya. Misalnya, teknologi blockchain, komputasi awan, dan IoT telah mempersingkat waktu yang dibutuhkan untuk meluncurkan produk baru dan mengubah bisnis, sehingga memungkinkan perusahaan untuk dengan cepat menyesuaikan operasi mereka dengan biaya rendah. Selama wabah Covid-19, perusahaan dengan digitalisasi tingkat tinggi, dapat dengan cepat membentuk 
kembali bisnis mereka untuk meminimalkan dampak buruk atau bahkan mendapatkan keuntungan dari krisis.

\section{b. Usaha Mikro}

Di Indonesia, beberapa lembaga atau instansi bahkan Undang-Undang (UU) memberikan definisi Usaha Mikro. Badan Pusat Statistik (BPS) memberikan definisi Usaha Mikro berdasarkan kuantitas tenaga kerja, yaitu untuk usaha mikro memiliki jumlah tenaga kerja kurang dari 5 orang. Pada tanggal 4 Juli 2008 ditetapkan UU No. 20 Tahun 2008 tentang Usaha Mikro, Kecil, dan Menengah. Definisi UMKM yang disampaikan oleh UU ini juga berbeda dengan definisi di atas. Menurut UU No 20 Tahun 2008 ini, yang disebut dengan Usaha Mikro adalah usaha produktif milik orang perorangan dan/atau badan usaha perorangan yang memenuhi kriteria Usaha Mikro. Adapun kriteria Usaha Mikro adalah sebagai berikut:

a. memiliki kekayaan bersih $\begin{array}{lr}\text { paling } & \text { banyak } \\ \text { Rp50.000.000,00 } & \text { (lima }\end{array}$ puluh juta rupiah) tidak termasuk tanah dan bangunan tempat usaha; atau

b. memiliki hasil penjualan tahunan paling banyak Rp300.000.000,00 (tiga ratus juta rupiah).

Prinsip-prinsip pemberdayaan Usaha Mikro yaitu:

a. penumbuhan kemandirian, kebersamaan, dan kewirausahaan Usaha Mikro untuk berkarya dengan prakarsa sendiri;

b. perwujudan kebijakan publik yang transparan, akuntabel, dan berkeadilan;

c. pengembangan usaha berbasis potensi daerah dan berorientasi pasar sesuai dengan kompetensi Usaha Mikro;

d. peningkatan daya saing Usaha Mikro; dan

e. penyelenggaraan perencanaan, pelaksanaan, dan pengendalian secara terpadu. 
Sedangkan tujuan pemberdayaan Usaha Mikro antara lain:
a. mewujudkan struktur perekonomian nasional yang seimbang, berkembang, dan berkeadilan;

b. menumbuhkan dan mengembangkan kemampuan Usaha Mikro menjadi usaha yang Tangguh dan mandiri; dan

c. meningkatkan peran Usaha Mikro dalam pembangunan daerah, penciptaan lapangan kerja, pemerataan pendapatan, pertumbuhan ekonomi, dan pengentasan rakyat dari kemiskinan.

\section{c. Hasil Penelitian Terdahulu}

Banyak

menunjukkan bahwa adopsi teknologi digital memainkan peran penting dalam merespons krisis pada masa pandemi Covid-19. Lutfi et al. (2020) meneliti tentang kebijakan social distancing pada 587 UKM di Indonesia menggunakan metode kuantitatif dengan desain survei.
Hasil penelitian menunjukkan bahwa pendapatan dan permintaan produk UKM menurun, bahkan ada UKM yang tidak memiliki pendapatan sehingga pelaku UKM memanfaatkan teknologi informasi untuk mengatasinya. Papadopoulos et al. (2020) membahas tentang penggunaan teknologi digital oleh UKM selama Covid-19. Implikasinya, UKM perlu menetapkan kebijakan untuk pengumpulan, pembagian, dan analisis data. UKM harus menyediakan sistem yang tepat dan staf pendukung untuk memastikan bahwa infrastruktur selalu tersedia, memastikan kelancaran operasi semua operasi bisnis (dalam platform digital UKM yang digunakan). Guo et al. (2020) meneliti tentang digitalisasi UKM dan respon krisis publik pada 518 UKM di Cina. Data dianalisis dengan menggunakan metode deskriptif dan korelasi. Hasilnya, digitalisasi telah memungkinkan UKM untuk merespons krisis publik secara efektif dengan memanfaatkan kemampuan dinamis mereka. Selain itu, digitalisasi dapat membantu 
meningkatkan kinerja UKM. Hulla \& Ramsauer (2020) mengupas tentang tantangan yang dihadapi oleh UKM dalam lingkungan bisnis digital. Dengan menggunakan studi literatur, terdapat lima kompetensi yang dibutuhkan UKM yaitu kompetensi Teknologi Informasi dan Komunikasi, fleksibilitas pribadi, kreativitas, kemampuan dalam kolaborasi dan organisasi, serta proses pemahaman dalam jaringan.

UMKM telah menjadi salah satu perhatian utama dalam studi kami. Penelitian pendahuluan mengenai UMKM dalam konteks inovasi dan kinerja sudah kami lakukan sebelumnya.

Feranita et al. (2017a), sampel penelitiannya adalah 113 UKM sektor meubelair, makanan dan minuman khas, kerajinan, batik, dan bordir di Kabupaten Jember. Menggunakan metode analisis regresi linier berganda. Variabel bebas adalah kepemimpinan, kapabilitas teknologi, pembelajaran, dan kekuatan kompetitif industri. Variabel terikat adalah inovasi UKM. Hasil penelitian menunjukkan bahwa kapabilitas teknologi dan kekuatan kompetitif industri berpengaruh terhadap inovasi UKM. Feranita et al. (2017b), dengan sampel penelitian dan variabel bebas yang sama, namun menggunakan metode analisis analisis jalur. Variabel terikat adalah kinerja UKM, sedangkan inovasi UKM menjadi variabel mediasi. Hasil penelitian menunjukkan bahwa inovasi cukup mampu menjadi mediasi yang memberikan pengaruh antara kapabilitas teknologi dan kekuatan kompetitif industri terhadap kinerja UKM.

Feranita (2018) melakukan studi literatur untuk mengeksplorasi isu-isu terkait pentingnya inovasi teknologi bagi UMKM yang berupa adopsi e-commerce dalam menghadapi revolusi industri 4.0. Paper ini mengantisipasi bahwa sumber daya manusia dan tingkat kesiapan infrastruktur akan mendukung inovasi teknologi UMKM.

Feranita et al. (2019), sampel penelitiannya adalah 165 UKM sektor makanan dan minuman khas di tujuh Kabupaten/Kota Jawa Timur. Variabel bebas adalah 
dukungan pemerintah, variabel mediasi adalah inovasi UKM, variabel terikat adalah kinerja UKM. Dengan menggunakan analisis jalur diperoleh hasil bahwa dukungan pemerintah berpengaruh terhadap inovasi dan kinerja UKM baik secara langsung maupun tidak langsung. Feranita et al. (2020), dengan menggunakan sampel, variabel mediasi, dan variabel terikat yang sama. Namun variabel bebasnya berbeda yaitu kepemimpinan transformasional dan transaksional. Diperoleh hasil bahwa apabila dilihat dari pengaruh totalnya, kepemimpinan transformasional lebih penting bagi peningkatan kinerja UKM di Indonesia daripada kepemimpinan transaksional.

\section{Identifikasi dan Perumusan} Masalah

Masalah utama yang ingin diperbaiki melalui kegiatan Pemberdayaan Usaha Mikro Tape menuju Digitalisasi yaitu:

1. Belum memiliki Surat Keterangan Usaha (SKU) dari Dinas Koperasi dan
Usaha Mikro Kabupaten Jember.

2. Belum memiliki pencatatan keuangan yang terstruktur, selama ini belum dipisah antara keuangan pribadi dan usaha.

3. Belum memiliki pengemasan produk yang menarik, selama ini masih dikemas secara sederhana menggunakan kantong plastik.

4. Belum memasarkan produk tape secara online, selama ini masih dipasarkan secara offline.

\section{Tujuan Kegiatan}

Kegiatan pengabdian kepada masyarakat ini bertujuan untuk:

1. Mengurus pembuatan SKU dari Dinas Koperasi dan Usaha Mikro Kabupaten Jember untuk usaha mikro tape milik Ibu Masfufah.

2. Meningkatkan pengetahuan Ibu Masfufah mengenai pencatatan keuangan yang terstruktur. 
3. Menambahkan variasi pengemasan produk tape milik Ibu Masfufah yang lebih menarik.

4. Membantu pemasaran produk tape secara online melalui media sosial Facebook dan Instagram.

\section{Manfaat Kegiatan}

Adapun manfaat yang dapat diperoleh setelah berlangsungnya kegiatan ini adalah:

1. Usaha mikro tape milik Ibu Masfufah memiliki SKU dari Dinas Koperasi dan Usaha Mikro Kabupaten Jember sehingga bisa digunakan sebagai legalitas kepemilikan usaha dan sebagai persyaratan untuk bisa memperoleh subsidi UMKM dari Pemerintah.

2. Ibu Masfufah selaku pemilik usaha mikro tape mengetahui cara pencatatan keuangan yang terstruktur sehingga antara keuangan pribadi dan usaha bisa terpisah.
3. Tape milik Ibu Masfufah semakin bertambah dan menarik variasi pengemasan produknya dari yang hanya dikemas dengan kantong plastik menjadi dikemas dengan kardus dan besek.

4. Produk tape milik Ibu Masfufah dipasarkan secara online melalui media sosial Facebook dan Instagram sehingga bisa dikenal masyarakat luas, tidak hanya daerah Ambulu dan Tanjungrejo.

\section{Kerangka \\ Masalah}

Pemecahan

Berdasarkan observasi awal (3 November 2020) disimpulkan bahwa solusi penyelesaian masalah utama adalah perlunya pemberdayaan usaha mikro tape menuju digitalisasi. Ada empat tahap kegiatan yang dilakukan, yaitu:

1. Tahap pengurusan SKU dari Dinas Koperasi dan Usaha Mikro Kabupaten Jember oleh Ibu Masfufah dengan didampingi 
mahasiswa di bawah bimbingan ketua pelaksana.

2. Tahap pencatatan keuangan yang terstruktur, yaitu pemisahan antara keuangan pribadi dan usaha yang dilakukan oleh mahasiswa di bawah bimbingan ketua pelaksana.

3. Tahap pengemasan produk tape menggunakan kardus dan besek, termasuk mencari pemasok besek yang harganya murah yang dilakukan oleh mahasiswa dan ketua pelaksana.

4. Tahap pemasaran produk tape secara online melalui media sosial Facebook dan Instagram, yang dimulai dengan sesi pemotretan tape dengan kemasan yang lebih menarik yang dilakukan oleh mahasiswa dan ketua pelaksana.

\section{Khalayak Sasaran}

Kegiatan pemberdayaan usaha mikro tape menuju digitalisasi dilakukan dengan mitra yang merupakan salah satu pemilik usaha mikro tape di desa Jatisari. Adapun identitas mitra sebagai berikut:

1. Nama: Masfufah

2. Jabatan: Pemilik

3. Nama IRT/Kelompok: UMKM Tape Masfufah Produk

4. Bidang Kegiatan: Kewirausahaan

5. Alamat: Dusun Grujugan, RT 002/RW 003, Desa Jatisari, Kecamatan Jenggawah, Kabupaten Jember

Pemilihan mitra tersebut berdasarkan analisis situasi yang telah dilakukan bahwa terdapat beberapa permasalahan pada mitra sehingga memerlukan Ilmu Pengetahuan dan Teknologi (Iptek) untuk menyelesaikan permasalahannya. Iptek yang digunakan adalah pemberdayaan usaha mikro tape menuju digitalisasi. Alasan memilih Iptek tersebut untuk mengatasi permasalahan aktivitas ekonomi mitra sehingga tercapai kriteria usaha mikro yang berdaya.

\section{Metode Kegiatan}

1. Observasi

$\begin{array}{lr}\text { Kegiatan } & \text { observasi } \\ \text { dilakukan } & \text { untuk } \\ \text { menganalisis } & \text { situasi }\end{array}$


permasalahan yang ada pada mitra sebagai dasar menyusun program dan kegiatan untuk menyelesaikan masalah.

Berdasarkan hasil observasi yang dilakukan pada tanggal 3 November 2020 ditemukan fakta bahwa di Desa Jatisari sebagian besar UMKM yang ada adalah produksi tape. Pemilihan usaha mikro tape milik Ibu Masfufah berdasarkan permasalahan yang dihadapi yaitu belum memiliki SKU, belum mengetahui pencatatan keuangan, pengemasannya masih sederhana, dan belum memasarkan produk secara digital.

2. Permohonan ijin kepada mitra

Ketua pelaksana mengajukan surat permohonan kepada Ibu Masfufah supaya bersedia menjadi mitra dalam kegiatan ini. Ibu Masfufah bersedia untuk bekerja sama dalam kegiatan ini yang ditandai dengan penandatanganan surat pernyataan kesediaan kerja sama program pengabdian kepada masyarakat yang bermaterai pada tanggal 7 Desember 2020.

3. Pelaksanaan

a. Pengurusan SKU dari Dinas Koperasi dan Usaha Mikro Kabupaten Jember

Pada tahap ini, mahasiswa di bawah bimbingan ketua pelaksana membantu Ibu Masfufah dalam mengurus SKU dari Dinas Koperasi dan Usaha Mikro Kabupaten Jember termasuk menyiapkan berkas-berkas yang diperlukan. Ibu Masfufah mengisi formulir SKU bagi usaha mikro dan melengkapi persyaratan SKU antara lain: 1) fotocopy KTP pemilik 
yang masih berlaku, 2)

pas foto pemilik ukuran

$3 \times 4$ (formal/rapi)

bukan swafoto/selfie, 3)

foto produk/tempat

usaha,

4) surat

pernyataan, dan 5) Surat

Keterangan Usaha dari

Desa. Berkas yang

sudah lengkap kemudian diserahkan ke

Dinas Koperasi dan

Usaha Mikro

Kabupaten Jember.

Pada tanggal 14

Desember 2020, usaha mikro tape milik Ibu Masfufah telah

memiliki

SKU.

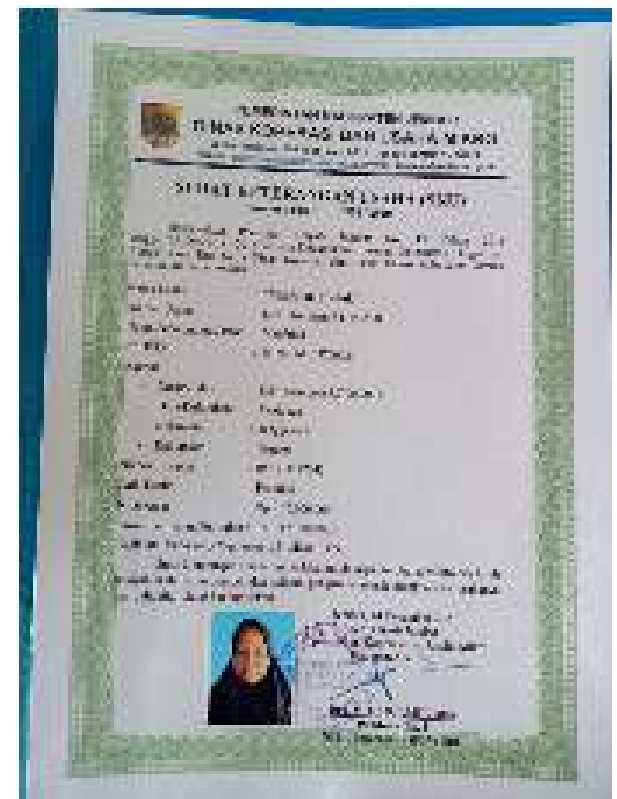

Gambar 1. SKU Masfufah Produk

b. Pelatihan pencatatan

keuangan

secara

terstruktur

Mahasiswa di bawah

bimbingan ketua

pelaksana memberikan

pelatihan pencatatan keuangan kepada Ibu

Masfufah dengan materi

jurnal umum dan laporan laba/rugi secara sederhana. Pada kegiatan ini, tim pelaksana 
menyampaikan materi

tentang pentingnya

melakukan pemisahan

keuangan pribadi dan

usaha. Kemudian

memberikan contoh

bagaimana mencatat keuangan usaha dengan

model akuntansi

sederhana supaya

mudah dimengerti dan

dapat diikuti oleh Ibu

Masfufah.

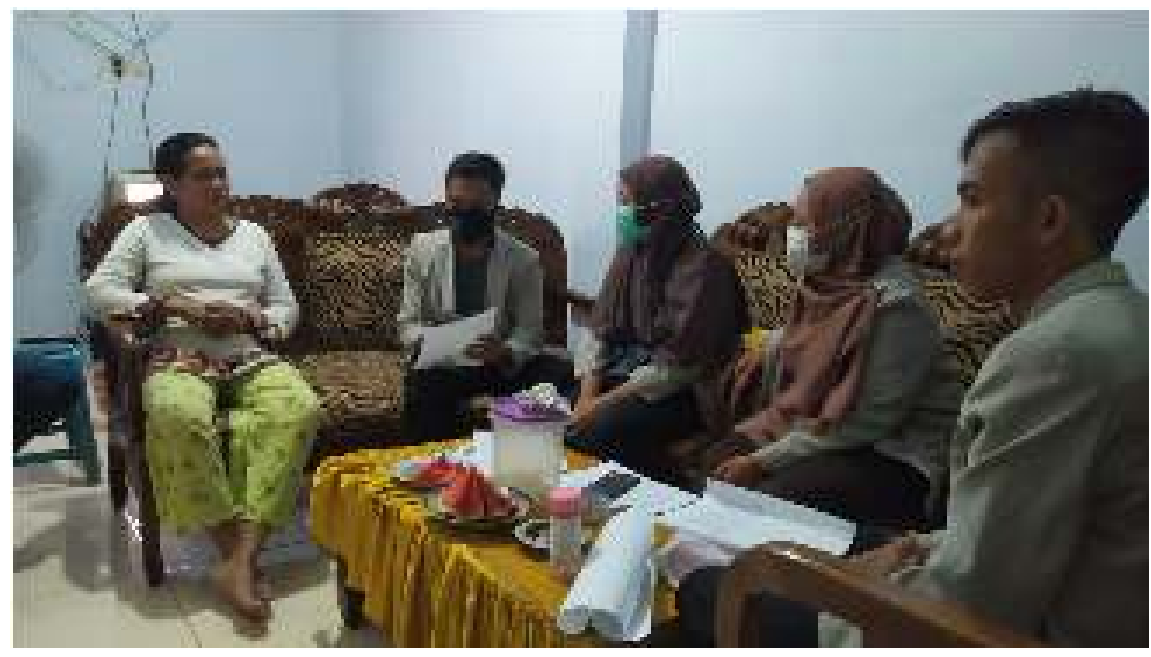

Gambar 2. Pelatihan Pencatatan Keuangan

c. Pengemasan produk tape yang lebih menarik

Ketua pelaksana

bersama mahasiswa

mencari pemasok besek

dengan harga yang

lebih murah. Melalui

pencairan Shopee,

diperoleh pemasok

besek dari Kabupaten

Trenggalek dengan

harga jual Rp700,-

dimana harga tersebut jauh lebih apabila

dibandingkan dengan besek yang dijual di Pasar Tanjung Jember seharga Rp3.000,-. Tim pelaksana juga memberikan alternatif kemasan produk tape dalam kardus. Pada kegiatan ini, tim pelaksana mendesain label kemasan supaya produk lebih menarik. 


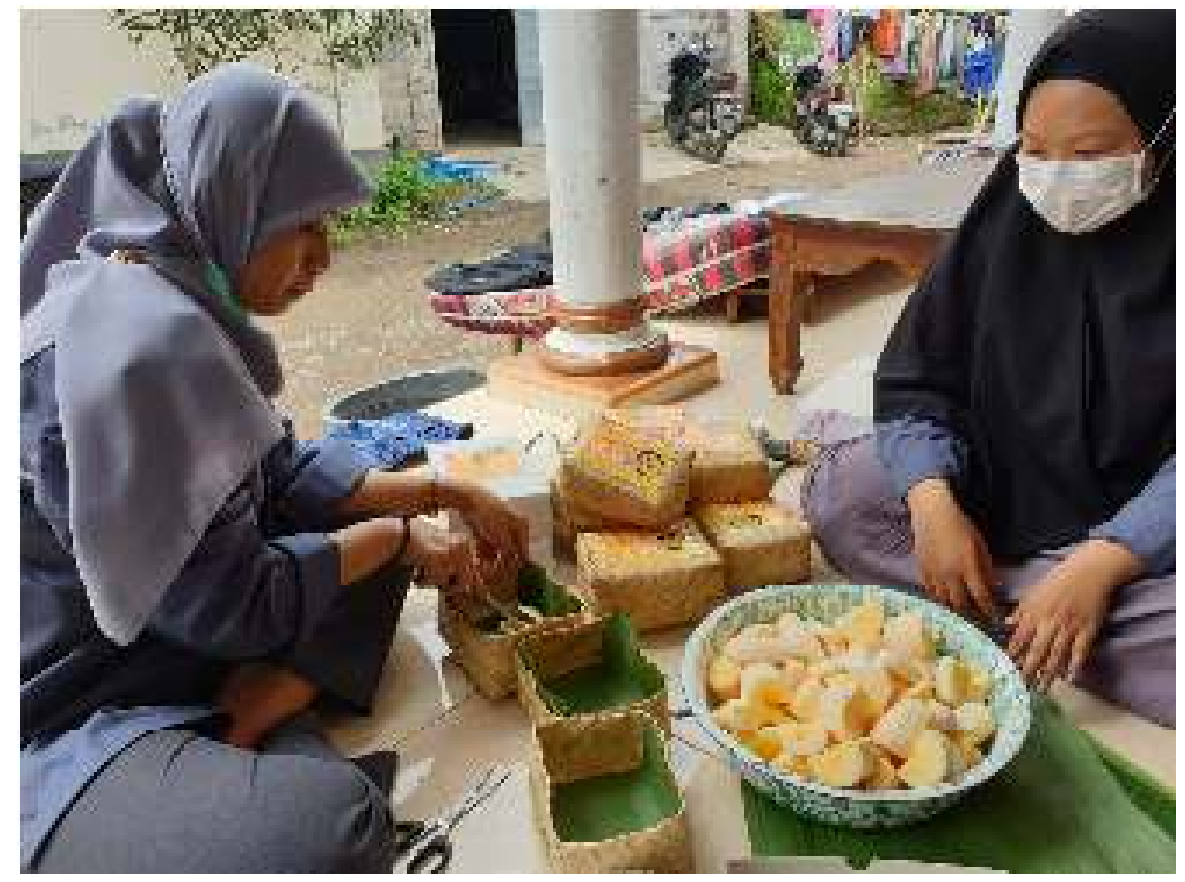

Gambar 3. Pengemasan Produk Tape

d. Pemasaran produk tape secara online

Kegiatan ini diawali dengan melakukan sesi pemotretan produk tape dengan kemasan barunya (besek dan kardus) beserta label yang sudah dicetak. Tim pelaksana membuat akun media sosial di Facebook dan Instagram, serta mengunggah foto-foto produk. Gambar produk yang telah diunggah juga diberi penjelasan mengenai produk dengan kalimat yang mudah dimengerti dan menarik sehingga saat ada konsumen yang melihat gambar menjadi tertarik untuk membeli produk tersebut. 

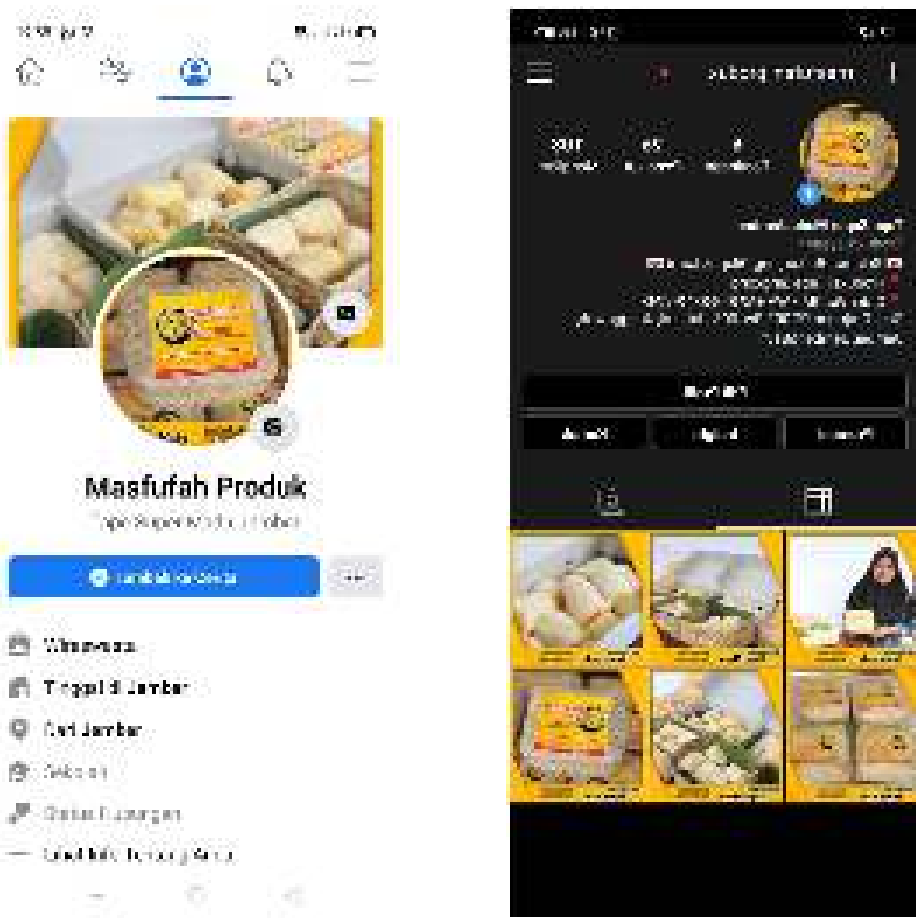

Gambar 4. Pemasaran Produk Tape melalui Facebook dan Instagram

\section{Evaluasi Kegiatan}

Kegiatan pemberdayaan usaha mikro tape menuju digitalisasi yang dilakukan oleh ketua pelaksana dan mahasiswa STIA Pembangunan Jember tahun 2020 dapat menghasilkan capaian dengan indikator sebagai berikut:

Tabel 2. Indikator Capaian Mitra

\begin{tabular}{|c|c|c|c|}
\hline No. & Indikator Capaian & Sebelum & Sesudah \\
\hline 1 & $\begin{array}{l}\text { SKU dari Dinas Koperasi dan } \\
\text { Usaha Mikro Kabupaten Jember }\end{array}$ & Belum memiliki & Sudah memiliki \\
\hline 2 & Pencatatan keuangan & $\begin{array}{l}\text { a. Masih gabung } \\
\text { antara } \\
\text { keuangan } \\
\text { pribadi dan } \\
\text { usaha } \\
\text { b. Belum } \\
\text { terstruktur }\end{array}$ & $\begin{array}{l}\text { a. Sudah terpisah } \\
\text { antara } \\
\text { keuangan } \\
\text { pribadi dan } \\
\text { usaha } \\
\text { b. Sudah } \\
\text { terstruktur }\end{array}$ \\
\hline 3 & Pengemasan produk tape & 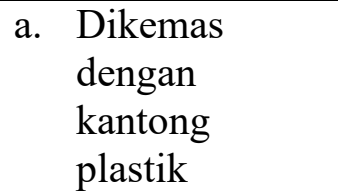 & $\begin{array}{l}\text { a. Dikemas } \\
\text { dengan besek } \\
\text { dan kardus }\end{array}$ \\
\hline
\end{tabular}




\begin{tabular}{|c|l|l|l|}
\hline No. & \multicolumn{1}{|c|}{ Indikator Capaian } & \multicolumn{1}{|c|}{ Sebelum } & \multicolumn{1}{|c|}{ Sesudah } \\
\hline 4 & Pemasaran produk tape & $\begin{array}{l}\text { Belum } \\
\text { memiliki label }\end{array}$ & $\begin{array}{l}\text { b. Sudah } \\
\text { memiliki label }\end{array}$ \\
\hline & Offline & $\begin{array}{l}\text { Online (Facebook } \\
\text { dan Instagram) }\end{array}$ \\
\hline
\end{tabular}

\section{DAFTAR PUSTAKA}

Bharadwaj, A., El Sawy, O. A., \& Pavlou, P. A. (2013). Digital business strategy: toward a next generation of insights. MIS Quarterly, 37(2): 471-482.

Feranita, N. V., Gumanti, T. A., Wahyudi, E., \& Puspitaningtyas, Z. (2017a). Determinants of Innovation in Small and Medium Enterprises in Jember, East Java, Indonesia. International Journal of Management and Administrative Sciences, 4(10), 15-23.

Feranita, N. V., Gumanti, T. A., Wahyudi, E., \& Puspitaningtyas, Z. (2017b). The Mediating Effect of Innovation on The Relationship of Leadership, Technological Capabilities, Learning, Industry Competitive Forces and The Performance of Small and Medium Enterprises. International Business Management, 11(7), 1532-1539.

Feranita, N. V. (2018). Technological Innovation as $A$ Key Strategy for Micro, Small and Medium Enterprises. Proceedings of the 2nd International Conference On Economics And Business (ICEB), Jember, 31-38.

Feranita, N. V., Nugraha, A., \& Sukoco, S. A. (2019). The Role of
Government Support for Innovation and Performance of SMEs. Jurnal Politico, 19(2): 124-136.

Feranita, N. V., Nugraha, A., \& Sukoco, S. A. (2020). Effect of transformational and transactional leadership on SMEs in Indonesia. Problems and Perspectives in Management, 18(3): 415-425.

Guo, H., Yang, Z., Huang, R., \& Guo, A. (2020). The digitalization and public crisis responses of small and medium enterprises: Implications from a COVID-19 survey. Frontiers of Business Research in China, 14: 1-25.

Hulla, M. \& Ramsauer, C. (2020). Competencies of Production in SMEs in Assembly Industries in a Digital, Volatile Business Environment. Technical Journal, 14(3): 388-395.

Lutfi, M., Buntuang, P. C. D., Kornelius, Y., Erdiyansyah, \& Hasanuddin, B. (2020). The impact of social distancing policy on small and medium-sized enterprises (SMEs) in Indonesia. Problems and Perspectives in Management, 18(3): 492-503. 
OECD. (2020). Coronavirus (COVID-19): SME Policy Responses.

Papadopoulos, T., Baltas, K. N., \& Balta, M. E. (2020). The use of digital technologies by small and medium enterprises during COVID-19: Implications for theory and practice. International Journal of Information Management, 55: 1-4.

Sebastian, I., Ross, J., Beath, C., Mocker, M., Moloney, K., \& Fonstad, N. (2017). How big old companies navigate digital transformation. MIS Quarterly, 16(3): 197-213.

Undang-Undang Republik Indonesia Nomor 20 Tahun 2008 tentang Usaha Mikro, Kecil, dan Menengah.

Vial, G. (2019). Understanding digital transformation: A review and a research agenda. The Journal of Strategic Information Systems, 28(2): 118-144.

Witschel, D., Döhla, A., Kaiser, M., Voigt, K. I., \& Pfletschinger, T.

(2019). Journal of Business

Economics, 89: 1023-1095 